\title{
SIZE AND DENSITY OF NON-ERODIBLE AGGREGATES IN SEDIMENTS OF SELECTED GULLIES AT NORTHERN IRAQ
}

\author{
Khalid F. Hassan \\ Yousif H. Al-Nasser \\ Omer N. Abid-Alkader \\ Soil and Water Resources Dept. / College of Agric. and Forestry/Mosul Univ. \\ E-mail: Khalid_a222@yahoo.com
}

\begin{abstract}
The objective of this study was to determine the morphometric characteristics and sediment size distribution as affected by position witin the gullies at northern region of Iraq. The plan area, maximum depression depth, maximum length $\mathrm{L}$ and severity index for each gully unit were measured. The size distribution of each gully unit was analyzed mechanically for major grain size fractions and were characterized statistically using various type of statistical measures (median size, sorting, and skewness). The results showed that the addition of finer/coarse materials in $1^{\text {st }}$ and $2^{\text {nd }}$ catchments was deposited under the prevailing low and high energy conditions respectively. Moreover the ability of the surface soil to accept the accelerated erosion, in these catchments was related to the stability of aggregates to the shearing force of running water. On the basis of this assumption, we can be expected that, the soil loss in the $1^{\text {st }}$ gully catchment was greater than compared to $2 \mathrm{nd}$, and it seems that the morphometric characteristics and sediment-grain size distribution alone would be insufficient for predicting soil loss from gullies.
\end{abstract}

Keywords: gully erosion, sediments, non-erodible aggregates.

Corresponding author: Khalid F. Hassan.

Received: 12/9/2012, Accepted: 18/2/2013.

\section{INTRODUCTION}

According to the international literature, gullies in agricultural areas are defined as channels with o05 to more than $30 \mathrm{~m}(\mathrm{SSSA}, 2001)$ and dimensions that cannot be easily corrected by means of simple implements in cultivation. Valentin et. al. (2005) reported that gully depth is often limited by the depth to the underlying rock which means that gullies are normally less than $2 \mathrm{~m}$ deep. However on deep alluvial and colluvial soils gullies may reach depths of 10 to $15 \mathrm{~m}$ (Poesen et al. 2003). Cheng et al., (2007) suggested that gully width (W) and depth (D) are a significant and useful index to estimate the volume of gully erosion especially in large scale surveying of gully.

US-SCS (1996) using W/D ratio of erosional channels found that in the cohesive soils, the width of the gullies is 3 times their depth while in non-cohesive soil, this ratio is 1.75 times. Vandekerckhove et al. (2000) in a research in the southeast of Spain found that the volume of gully erosion had a positive correlation with W/D ratio and a negative correlation with width. Their finding revealed that gully widening had a more important role than gully deepening. Nachtergaele et al. (2002) reported that gully length is a good estimator of gully volume and found a power relationship between them.

$$
\mathrm{V}=\mathrm{b} \mathbf{L}^{1.27}
$$$$
\mathbf{R}^{2}=\mathbf{0 . 6 4}
$$ 
In which $\mathrm{V}$ is gully volume $\left(\mathrm{m}^{3}\right), \mathrm{L}$ is gully length $(\mathrm{m})$, and $\mathrm{b}$ are 0.05 . Capra et al. (2005) in their model calibration for estimation of gully volume in Sicily, Italia, found a relationship between gully volume and length. To find higher $\mathrm{R}$ square, they used stepwise method in SPSS software to indicate the influence of several indices such as, catchment area, catchments length, catchment gradient, gully length, and gully slope on the volume of gully erosion. The final equation (4) indicated that $\mathrm{R}^{2}$ is a little better than equation 3 , but the most important factor is the length of gully to predict the volume of gully erosion

$\mathrm{V}=\mathbf{0 . 0 0 8 2} \mathrm{L}^{1.416}$

$\mathbf{R}^{2}=\mathbf{0 . 7 2}$

In gully, the size distribution of sediment at its point of deposition is primarily related to the W/D of gully and diameter of the particles (Wilson,et al 2010). The sediment load leaving a depositional area is closely related to the transport capacity of flow. When sediment load exceeds transport capacity; sediment is deposited at a rate proportional to the difference between transport capacity and sediment load according to the following:

$$
\mathbf{D d}=\alpha(\mathrm{Tc}-\mathrm{g})
$$

Where;

$\mathrm{Dd}=$ the deposition rate (mass / area. time)

Tc $=$ transport capacity (mass / width.time)

$\mathrm{g}=$ sediment load (mass / width. time)

$\alpha=$ a parameter describing the likelihood of a given sediment size deposit (length ${ }^{-1}$ )

The transport capacity equation must also account for this non-uniformity and must shift transport capacity among particle sizes as deposition removes some size more rapidly than other.

The study of gully erosion has to date been neglected due to the difficulties of investigation and of prediction (Valentin et al., 2005). Nevertheless, in recent years, this erosion form has attracted increasing interest in erosion studies, as seen in the last international conferences held in Mississippi, USA, in 2004 (Soufi and Isaie 2004). Knowledge of soil erosion particularly the gully erosion processes within the landscape is of fundamental importance because contributes significantly to the total sediment yield of a catchment. Therefore the objective of this study was to measure the morphometric and sediment size distribution of two catchments affected by gully erosion at northern region of Iraq as a function of distance from a gully.

\section{MATERIALS AND METHODS}

The study was carried out on two catchments affected by gully erosion at northeastern Iraq. Those are the Al-Mefri and Zemar catchments with an eroded area larger than $10 \mathrm{~km}^{2}$. They were selected because many gullies are developed in them with differences in landscape characteristics. These catchments fell within the physiographic unit of the upper Jezira, with median slopes of $10 \%$. The region is characterized by being deep, well-drained, with calcareous and gypsiferous soils The dominant land use is field crop and pasture.. 
Climatology, the gullies are distributed in arid and semi-arid climatic zones with mean annual rainfall ranging from 250 to $500 \mathrm{~mm}$ and rainfall erosivity $\left(\mathrm{EI}_{30}\right)$ ranged from 80 to $95 \mathrm{MJ} \mathrm{mm} \mathrm{ha}^{-1} \mathrm{~h}^{-1}$ (Hussein 1986) which resulting somewhat greater surface runoff and, consequently, particles are dragged away.

Two classical gullies in two transect at these catchments were selected. Each transect was divided into 3 segments (inlet, mid-stream and outlet) spaced $500 \mathrm{~m}$ apart. Thus each transect was $1500 \mathrm{~m}$ long with two position located in the center of the gully. In each segment, depth, top and bottom width of gully and cross section were measured by tape meter and severity index of each unit was calculated as follows:

$$
\begin{gathered}
\text { Length of gullies in alluvial valley } \\
\text { Severity Index SI = } \\
\text { Total length of alluvial valley }
\end{gathered}
$$

The relationship between the width and length of gully erosion as dependent variable and depth of gullies as independent variables was considered using stepwise method in Minitab soft package

Soil samples represented each segment (inlet, intermediate and outlet) of the two gullies were collected between December 2011 and April 2012. These samples were separated for major grain size fractions $(4.75,2,1,0.50,0.25$ and $0.75 \mathrm{~mm}$ ) according to the procedure mentioned by Kemper and Rosenau (1986). Coarse grain size fractions $>0.75 \mathrm{~mm}$ were separated mechanically by using the standard sieving techniques (Folk 1980). Fine -fraction size distribution (Silts and clays) $<0.75 \mathrm{~mm}$ was determined in each sample by sedimentation (pipette technique) as described by Torresan et. al (1997). Mean weight diameter (MWD) for each sediment sample was calculated as follows;

$$
\text { MWD }=\sum^{\mathbf{n}} \Delta \mathbf{i} \mathbf{d i}
$$

Where;

$$
\begin{aligned}
& \mathrm{MWD}=\text { mean weight diameter }(\mathrm{mm}) \\
& \Delta \mathrm{i} \quad=\text { fraction of size in total sediment } \quad \mathrm{Di}=\text { diameter of fraction }(\mathrm{mm})
\end{aligned}
$$

Data for each site were analyzed statistically using statistical measures (median size, sorting, and skewness) obtained normally from a Cumulative Frequency Distribution (CDF) as described by Pettijohn(1957) and presented in table (1).

Table (1): The fundamental statistical measures used in the study.

\begin{tabular}{|c|c|c|}
\hline Attribute & Technical name & Statistical name* $^{*}$ \\
\hline Average & Measure of central tendency & Median(Md) or 50 percentile \\
\hline Sorting & Dispersion & Coefficient of Sorting $=\sqrt{\mathrm{Q} 3 / \mathrm{Q} 1}$ \\
\hline Symmetry & Skewness & Coefficient of Skewness $=\mathrm{Q} 1 \mathrm{Q} 3 /(\mathrm{Md})^{2}$ \\
\hline
\end{tabular}

$* \mathrm{Md}=$ median which is that size $50 \%$ of the materials is bigger and $50 \%$ smaller

$\mathrm{Q} 3=$ is the 75 percentile; is the $75 \%$ is smaller and $25 \%$ larger

$\mathrm{Q} 1=$ is the 25 percentile; is the $25 \%$ is smaller and $75 \%$ is large 


\section{RESULTS AND DISCUSSION}

A series of analyses have been made on data from gullies which include :

1- Morphometric Study; The general morphological characteristics of studied gullies of the two catchments are shown in table (2). For the characteristics of contribution area, width, length, slope length above the gully, the gullies tended to be not similar.

In these gullies, deep cuts were observed, reaching a depth of 0.2 to $1.5 \mathrm{~m}$ in the recovering gully (Table 2 ). This characteristic, together with the soil morphological observed in the studied areas indicate the probable causes for the occurrences of gullies with great area and volume in this region. As alternatives to gully length, there are three other measures of the extent of gully erosion: gully area, gully volume, and the number (or density) of gully heads. Gully area is a better measure than length of the amount of land taken from production. Gully volume emphasizes the sedimentation effects and should be associated with the rain erosivity in the two studied catchment. The top width of the represented gullies varied between between 1.2 and 3.6 meters. The bottom width of the gullies was between 1 and 10.5 meters. The volume of gully erosion was calculated between 133 (catchment-1) and $23000 \mathrm{~m}$ (catchment-2).

Table (2): Relationship between morphometric parameters of the studied gullies.

\begin{tabular}{|c|c|c|c|c|c|c|}
\hline \multirow{2}{*}{ Position } & \multicolumn{3}{|c|}{ Catchment-1 } & \multicolumn{3}{c|}{ Catchment -2} \\
\cline { 2 - 7 } & Depth $(\mathrm{m})$ & Wide(m) & W/D & Depth(m) & Wide(m) & W/D \\
\hline Inlet & 1.5 & 1.5 & 1.00 & 1.5 & 3.3 & 2.20 \\
\hline Intermediate & 1.3 & 2.5 & 1.92 & 2.5 & 3.5 & 1.40 \\
\hline Outlet & 0.9 & 3.5 & 3.88 & 3.5 & 3.6 & 1.02 \\
\hline Mean & 1.5 & 2.2 & 1.46 & 2.2 & 3.2 & 1.45 \\
\hline
\end{tabular}

In the $1^{\text {st }}$ catchment the gully density is around $4.5 \mathrm{~km}$ per $\mathrm{km}^{2}$, the severity index may be as high as $55 \%$. But in parts of the 2 nd catchment, where a gully density of $4 \mathrm{~km}$ per $\mathrm{km}^{2}$ common, there are about $45 \%$.

On this basis, the $2^{\text {nd }}$ catchment has a much greater potential for gulling, so if emphasis is placed on the effects of sediment coming from the gullies in future, then $2^{\text {nd }}$ has the higher priority. So the maximum possible density of gulling by the possible distribution of gullies in the alluvial valleys. The density of alluvial valleys varies, and the density of gullies will also vary for the same degree of degeneration (Erkan et.al. 2003).

The critical flow velocity for initiation of erosion and the water discharge distribution along the flow lines determine the shape of the gully (length and depth).

Therefore, we can expect that the most important factors controlling the rates of gully head advance are "mechanism of erosion" and "hydrological conditions". The latter includes rainfall intensity and duration, antecedent moisture, land management and condition. These factors are too complex to be represented as figures inequations 
The results of statistical analysis indicated that there is a linear relationship between W/D ratio and gully length by the following regression equation

\section{$\mathrm{W} / \mathrm{D}=3.16-0.001095 \mathrm{~L} \quad \mathrm{R}^{2}=0.68$}

which indicated that $68 \%$ of variation in the W/D of gully erosion was interpreted by the length of gullies. In other words, it implies that with an increases in the gully length, 0.66 unit of W/D ratio will be increased.

2-Mechanical composition: The result of mechanical composition analysis of the two studied gullies as shown in table indicates that the size distribution of sediment varies enormously from one gully to another. This variation can be seen clearly from the mean weight diameter of sediments in each gully unit of the two studied catchment . Sediments of the inlet plain in the two catchments were found to have relatively high MWD (2.82 and2.58 $\mathrm{mm})$ and decreased to reach $(1.44$ and $1.71 \mathrm{~mm})$ in the outlet plains of the same catchments(Table 3 and 4). This result confirms the fact that the size distribution of sediments at its point of deposition is related to mechanical composition of sediments ( Erkan et. al. 2003) . Large and dense particles are readily deposit, whereas fine and light weight particles travel much farther down the gully.

As a result, the gradation of particles in a depositional area, in this case is from coarse to fine in down gully direction. Sediments were classified as gravelly at inlet points and as sandy in the intermediate and outlet of the two catchments. Table 2 and 3 show in general that gravel $>4.75 \mathrm{~mm}$ was the predominant size fraction in the sediments of inlet points of the 2 catchments, whereas coarse sand $2.00-1.00 \mathrm{~mm}$ in the intermediate and fine sand0.50-0.25 $\mathrm{mm}$ in the outlet.

Table (3): Mechanical composition of sediments at different positions in the gully within catchment 1

\begin{tabular}{|c|c|c|c|c|c|c|}
\hline \multirow{2}{*}{$\begin{array}{c}\text { Sieves } \\
\mathrm{mm}\end{array}$} & \multicolumn{2}{|c|}{ Inlet } & \multicolumn{2}{c|}{ Intermediate } & \multicolumn{2}{c|}{ Outlet } \\
\cline { 2 - 7 } & $\%$ & $\begin{array}{c}\text { Cumulative } \\
\text { Weight } \%\end{array}$ & $\%$ & $\begin{array}{c}\text { Cumulative } \\
\text { Weight\% }\end{array}$ & $\%$ & $\begin{array}{c}\text { Cumulative } \\
\text { Weight } \%\end{array}$ \\
\hline$<0.075$ & 10.1 & 10.1 & 3.4 & 3.4 & 1.3 & 1.3 \\
\hline $0.075-0.25$ & 8.0 & 18.1 & 4.4 & 7.8 & 6.8 & 8.1 \\
\hline $0.25-0.50$ & 4.0 & 22.1 & 10.6 & 18.4 & 19.1 & 27.2 \\
\hline $0.50-1.00$ & 5.4 & 27.5 & 22.9 & 41.3 & 30.3 & 57.5 \\
\hline $1.00-2.00$ & 9.5 & 37.0 & 28.5 & 69.8 & 15.0 & 72.5 \\
\hline $2.00-4.75$ & 21.7 & 58.7 & 23.6 & 93.4 & 22.7 & 95.2 \\
\hline$>4.75$ & 41.3 & 100 & 6.6 & 100 & 4.8 & 100 \\
\hline $\mathrm{MWD}(\mathrm{mm})$ & 2.82 & & 1.66 & & 1.44 & \\
\hline
\end{tabular}

2-Statistical description: Five critical points on the cumulative curve (Md,Q1, Q2, and Q3) and two statistical parameters (So, and Sk) in sediments of the gullies were computed and statistically analyzed as shown in table (3). 
The sorting degree (So) of percent sediment sizes on the cumulative curve ,in general indicated that the studied plain have a well -sorted sediment according to Trask sorting scale(Bull and Kirkby 1997)).Sediment of inlet, intermediate and outlet points of the two catchment have about the same sorting degree $(1.87$ and $1.84 \mathrm{~mm}$ respectively), but differ in their Md values. This result means that there is no correlation between sorting degree and Md values. Pettijhon (1957) state that the sediment with $\mathrm{Md}$ near the grade of fine sand $(\mathrm{Md} \approx 0.2 \mathrm{~mm})$ are the better sorted, sediments coarser and finer are more poorly. According to this statement ,the sediment of whole studied catchments are better sorted $(\mathrm{Md}=0.29,0.14$ and $0.12 \mathrm{~mm}$ for inlet, intermediate and outlet respectively). This relation is attributed the properties of fine sand(would be easily moved : the coarser and finer grade move by surface creep ,would tend to lag behind.The coefficient of skewness (Sk) as shown in table ( 5 ) indicated that all sediment have a positive skewness (right skew).This means that the whole studied gullies - have a sediment of fine fraction exceeding the coarse .This result is in a agreement with the result of Sidorchuk, et. al. (2003) who discussed the relation between $\mathrm{Md}$ and $\mathrm{Sk}$ and have shown that the finest sediment should be normally and highly skewed toward fine fraction.

Table (4): Mechanical composition of sediments at different positions in the gully Within catchment 2

\begin{tabular}{|c|c|c|c|c|c|c|}
\hline \multirow{2}{*}{$\begin{array}{c}\text { Sieves } \\
\mathrm{mm}\end{array}$} & \multicolumn{2}{|c|}{ Inlet } & \multicolumn{2}{c|}{ Intermediate } & \multicolumn{2}{c|}{ Outlet } \\
\cline { 2 - 7 } & $\%$ & $\begin{array}{c}\text { Cumulative } \\
\text { Weight } \%\end{array}$ & $\%$ & $\begin{array}{c}\text { Cumulative } \\
\text { Weight } \%\end{array}$ & $\%$ & $\begin{array}{c}\text { Cumulative } \\
\text { Weight } \%\end{array}$ \\
\hline$<0.075$ & 2.0 & 2.0 & 1.7 & 1.7 & 10.2 & 10.2 \\
\hline $0.075-0.25$ & 12.1 & 14.1 & 3.2 & 4.9 & 12.6 & 22.8 \\
\hline $0.25-0.50$ & 11.3 & 25.4 & 7.3 & 12.2 & 14.7 & 37.5 \\
\hline $0.50-1.00$ & 7.0 & 32.4 & 13.3 & 25.5 & 18.4 & 55.9 \\
\hline $1.00-2.00$ & 10.4 & 42.8 & 34.3 & 59.8 & 11.6 & 67.5 \\
\hline $2.00-4.75$ & 23.2 & 66.0 & 19.6 & 79.4 & 11.7 & 79.2 \\
\hline$>4.75$ & 34.0 & 100 & 20.6 & 100 & 20.8 & 100 \\
\hline$M W D(\mathrm{~mm})$ & 2.58 & & 2.43 & & 1.71 & \\
\hline
\end{tabular}

From the results of this investigation, it was possible to conclude that there are somewhat wide variations in morphometric and sediment grain size distribution materials in $1^{\text {st }}$ and $2^{\text {nd }}$ catchments is deposited under the prevailing low and high energy conditions respectively. Moreover the ability of a surface soil to accept the accelerated erosion is related to the stability of aggregates to raindrop impact and to the resistance to shearing force of running water. On the basis of this assumption, we can expect that, the soil loss in the gully catchment was greater than that from the 2 nd, and could be said that the morphometric and sediment-grain size distribution alone would be insufficient for a predicting soil loss from gullies. 
Table (5): Critical size values and statistical measures of sediments for the studied catchments

\begin{tabular}{|c|c|c|c|c|c|c|}
\hline \multirow{2}{*}{ Attribute } & \multicolumn{3}{|c|}{ Catchment -1 } & \multicolumn{3}{c|}{ Catchment-2 } \\
\cline { 2 - 7 } & Inlet & Intermediate & Outlet & Inlet & Intermediate & Outlet \\
\hline Md & 1.65 & 0.81 & 0.62 & 1.68 & 1.60 & 0.70 \\
\hline Q1 & 0.61 & 0.50 & 0.25 & 0.82 & 0.72 & 0.41 \\
\hline Q3 & 2.1 & 1.70 & 1.4 & 2.80 & 2.60 & 2.00 \\
\hline So & 1.87 & 1.84 & 2.36 & 1.84 & 1.90 & 2.20 \\
\hline Sk & 0.47 & 1.29 & 0.91 & 0.81 & 0.73 & 1.76 \\
\hline
\end{tabular}

\section{حجم وكثافة تجمعات التربة غير القابلة للتعرية في رواسب أخاديد مختارة من شمال العراق}

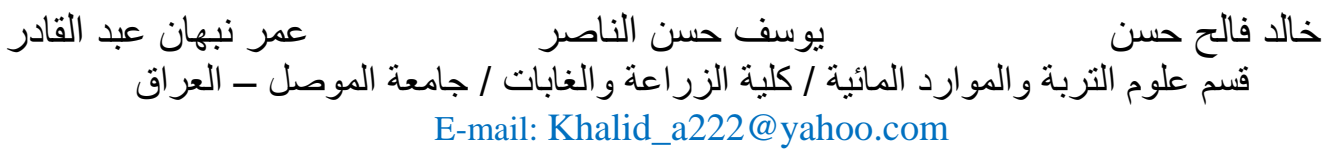

\section{الخلاصة}

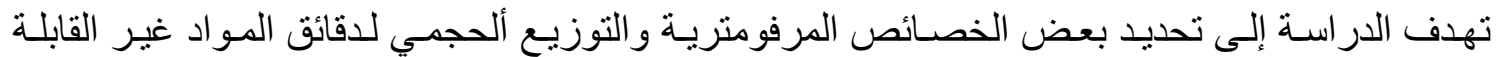

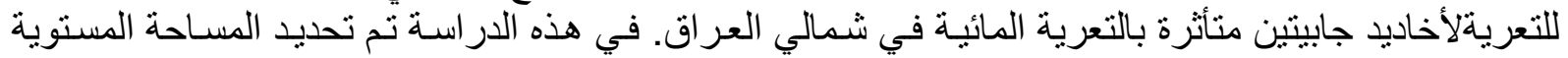

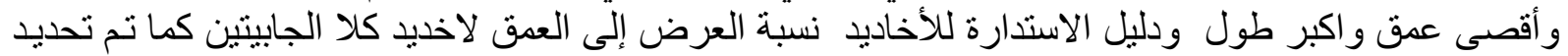

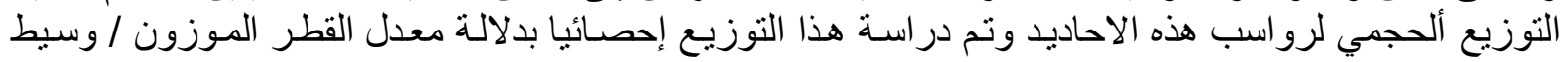

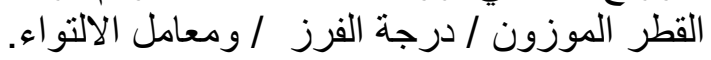

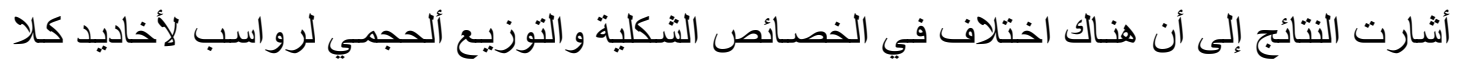

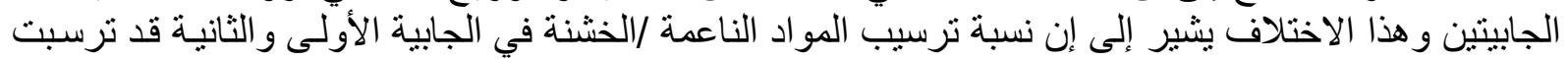

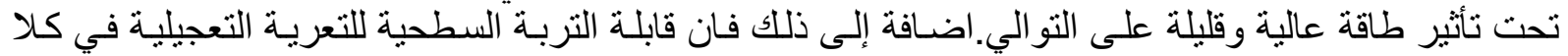

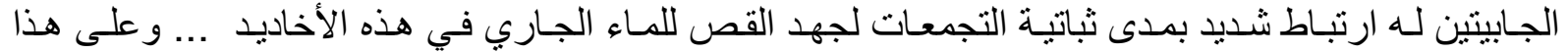

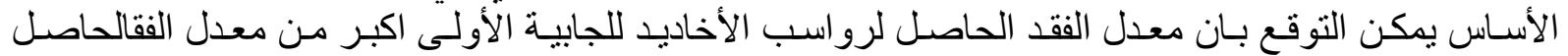

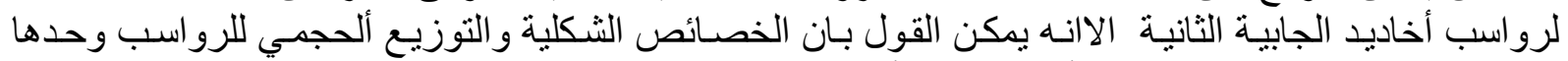

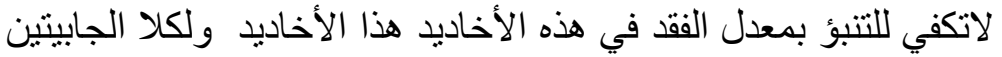

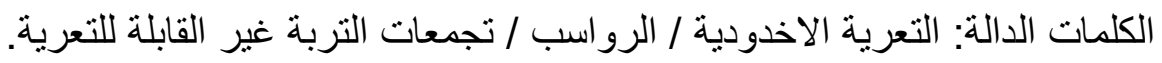
تاريخ تسلم البحث: 2012/9/12 ، وقبوله: 2013/2/18.

\section{REFERENCES}

Anonymous(1966) Technical Release No. 32(Geology), US Department of Agriculture. Washington. DC, 125-142.

Arrough, S. A (1995). Relation Of Some Properties To Its Erodibility .Ph.D.Thesis Ain Shamas Univ., Egypt.

Bull, L. J. and Kirkby, M. J. (1997) Gully processes and modeling. program. Physical Geograpgy. 21(3), 354-374.

Capra, J., S. J. Bennett and K. M. Robinson.(2000). Processes of Ephemeral Gully Erosion. International Journal of Sediment Research 15(1): 31-41. 
Cheng, H., Zou, X., Wu, C., Zhang, C., Zheng, Q. and Jiang, Z.,(2007). Morphology parameters of ephemeral gully on the loess plateau of China. Soil and Tillage Research, 94:4-14.

Erkan I., David G., and T.,Robert (2003)A sediment transport model for incision of gullies on steep topography. Water Resources Researches, 39: 1103-1167

Hassel, R., and van Asch, T. (2003). Modeling gully erosion for a small catchment on the Chinese loess plateau. Catena, 54, 131-146.

Kemper, W., and R. Rosenau (1986). Aggregate stability and distribution. In Klute .Methods Of Soil Analysis .Part 1, 2nd ed . Am. Soc. of Agr. USA

Nachtergaele, J. and J, Poesen, (2002). Spatial and temporal variations in resistance of loess-derived soils to ephemeral gully erosion. Journal of Soil Sciences. 53: 449-464

Pettijohn,F.(1957).Sedimentary Rockes.Copyright by Harper and Brothers ,USA.

Poesem, J., Nachtergaele , J., Verstraeten, G. and Valentin, C.(2003). Gully erosion and environmental change: Importance and research needs. Catena, 50:91-133,.

Sidorchuk, A., Marker, M., Moretti, M. and G. Rodolfi, (2003) Gully erosion modeling in semiarid catchments of Southern Africa. Catena 50: 507-525.

Soufi, M. and H., Isaie,(2004). The Relationship Between Gully Characteristics and Sediment Production In The Northeast of Iran. Agric. Res. and Education Organ. Researches. Center for Agriculture. and Natural Resesearches, S/N $83 / 1153,130 \mathrm{pp}$.

Valentin, C., Poesem, J. and L. Young, (2005). Gully erosion: Impacts, factors and control. Catena, 63:132-153.

Vandekerckhove, L., Poesen, J., Wijdenes, D., Gyssels, G and E. Luna, (2000). Characteristics and controlling factors of bank gullies in two semi-arid Mediterranean environments. Geomorphology, 33:37-58.

Wilson, G.V. (2010).Ephemeral Gully Erosion: Impact On Physical Soil Quality and Crop Yield Research Hydrologist, USDA-ARS NSL. 